\title{
Bonamia exitiosa transmission among, and incidence in, Asian oyster Crassostrea ariakensis under warm euhaline conditions
}

\author{
C. Audemard ${ }^{1, *}$, R. B. Carnegie ${ }^{1}$, K. M. Hill ${ }^{2}$, C. H. Peterson ${ }^{3}$, E. M. Burreson ${ }^{1}$ \\ ${ }^{1}$ Virginia Institute of Marine Science, College of William \& Mary, PO Box 1346, Gloucester Point, Virginia 23062, USA \\ ${ }^{2}$ College of Charleston, 205 Fort Johnson Road, Charleston, South Carolina 29412, USA \\ ${ }^{3}$ Institute of Marine Sciences, University of North Carolina at Chapel Hill, 3431 Arendell Street, Morehead City, \\ North Carolina 28557, USA
}

\begin{abstract}
Previously reported in Australia, New Zealand, and more recently in Europe, the protistan parasite Bonamia exitiosa was also reported in the mid-Atlantic region of the USA after causing serious mortalities there in the Asian oyster Crassostrea ariakensis. At the time, this oyster was being considered for introduction, and the potential consequences of introducing this species were being assessed using field and laboratory studies. B. exitiosa emerged as the most serious disease threat for this oyster species, especially under warm euhaline conditions and for oysters $<50 \mathrm{~mm}$ in size. To better evaluate how quickly this parasite may be able to spread among C. ariakensis, we investigated $B$. exitiosa transmission and incidence in $C$. ariakensis. During a first trial, potential direct transmission of $B$. exitiosa was evaluated by cohabitating infected $C$. ariakensis with uninfected $C$. ariakensis under in vivo quarantine conditions. In a second experiment, $B$. exitiosa incidence was estimated in situ by determining its prevalence in $C$. ariakensis deployed in an enzootic area after 4, 7, 14, 21 and $28 \mathrm{~d}$ of exposure. Results suggest that under warm euhaline conditions $B$. exitiosa can be transmitted among $C$. ariakensis without requiring any other parasite source and that parasite incidence may be at least as high as $40 \%$ after only $4 \mathrm{~d}$ exposure to an enzootic area. These results underscored the severity of the bonamiasis disease threat to $C$. ariakensis and provided further evidence that efforts to build an aquaculture industry based on $C$. ariakensis in the eastern USA might have been thwarted by parasitic disease.
\end{abstract}

KEY WORDS: Haplosporidia · Bonamia exitiosa · Crassostrea ariakensis · Disease transmission · Incidence

Resale or republication not permitted without written consent of the publisher

\section{INTRODUCTION}

As was revealed during field trials over the last decade in waters of the southeastern USA, the most significant disease threat known for the Asian oyster Crassostrea ariakensis is the microcell haplosporidian parasite Bonamia exitiosa (Hine et al. 2001, Burreson et al. 2004, Hill et al. 2010). Infection by B. exitiosa was first reported in 2003 after triploid $C$. ariakensis that had been deployed as small seed in Bogue Sound, North Carolina, experi- enced catastrophic and rapid mortality in midsummer (Burreson et al. 2004). Previously unnoticed in native Ostrea stentina (= Ostreola equestris; Shilts et al. 2007) present throughout the region (Carnegie et al. 2006), B. exitiosa is particularly pathogenic in young $C$. ariakensis $<50 \mathrm{~mm}$ in shell height and caused mortality within weeks of deployment in Bogue Sound (Bishop et al. 2006). Additional field and laboratory studies demonstrated that $B$. exitiosa was most infective and pathogenic under a combination of warm $\left(>20^{\circ} \mathrm{C}\right)$ and 
polyhaline to euhaline ( $>20 \mathrm{psu}$ ) conditions (Bishop et al. 2006, Audemard et al. 2008a,b, Carnegie et al. 2008). B. exitiosa has been reported worldwide in various hosts and locations, for example: Ostrea chilensis in New Zealand (Hine et al. 2001, Berthe \& Hine 2003), O. angasi in Australia (Corbeil et al. 2006), O. edulis in Europe (Abollo et al. 2008), and O. stentina in Tunisian waters and in North Carolina, USA (Hill et al. 2010), although it has never been observed infecting $C$. ariakensis in the Asian environments to which it is native.

To further assess the epizootiology of Bonamia exitiosa in Crassostrea ariakensis, we evaluated the transmissibility and incidence (i.e. rate of infection acquisition) of the parasite among C. ariakensis. While the native oyster species Ostrea stentina is known to harbor B. exitiosa in North Carolina (Carnegie et al. 2006), we hypothesized that the parasite may be able to complete its life cycle in $C$. ariakensis in the absence of $O$. stentina and that transmission among $C$. ariakensis may be direct. This hypothesis was tested in a laboratory experiment by placing infected $C$. ariakensis as cohabitants with naïve $C$. ariakensis. A previous similar experiment had resulted in an absence of parasite transmission (Audemard et al. 2008a); however, we suspected that suboptimal water quality in the experimental aquaria may have influenced these results and felt that this experiment had to be repeated under better conditions. Our second objective was to investigate $B$. exitiosa incidence on a time scale ranging from 4 to $28 \mathrm{~d}$ exposure. Previous studies revealed that $B$. exitiosa could be detected within a few weeks after deployment of $C$. ariakensis in Bogue Sound during summer and early fall (Carnegie et al. 2008). We suspected, however, that infection may occur even more rapidly. We investigated this hypothesis during the present study.

\section{MATERIALS AND METHODS}

\section{Trial 1: Bonamia exitiosa transmission}

On 20 June 2007, a subset of several hundred triploid Crassostrea ariakensis produced in quarantine (Spawn 3MXWCA07-1) at the Virginia Institute of Marine Science (VIMS) Aquaculture Genetics and Breeding Technology Center was transferred to the University of North Carolina Institute of Marine Sciences (IMS), located in Morehead City, North Carolina. The oysters were placed in upwellers receiving unfiltered euhaline seawater (>30 psu) from Bogue
Sound, where B. exitiosa is enzootic (Carnegie et al. 2008, Hill et al. 2010).

On 24 July 2007, 35 d after deployment, these oysters (= NC Crassostrea ariakensis) were retrieved and shipped overnight back to VIMS. Our subsequent experiment was performed under quarantine conditions and was begun when the NC C. ariakensis were returned to VIMS, on 25 July 2007. Bonamia exitiosa prevalence and mean infection intensity were determined in a sample of $30 \mathrm{NC} C$. ariakensis using PCR and histology (see ' $B[$.] exitiosa prevalence and ... intensity'). On the same date, 30 C. ariakensis from the same cohort maintained in polyhaline conditions at the VIMS hatchery and not sent to North Carolina for parasite exposure (=VA $C$. ariakensis) were sampled for $B$. exitiosa diagnosis in order to confirm that these control oysters had indeed remained free of the parasite. No Bonamia sp. has ever been observed in samples from Chesapeake Bay, Virginia. Average sizes of these animals were $22 \pm 3$ and $22 \pm 4 \mathrm{~mm}$ (mean $\pm \mathrm{SD}$ ) for NC and VA C. ariakensis, respectively.

On the day the trial began, the NC and VA Crassostrea ariakensis were carefully rinsed and any dead animals (empty shells) were removed. As treatment aquaria, 3 replicate 401 aquaria containing $50 \mathrm{NC} \mathrm{C}$. ariakensis and 50 VA $C$. ariakensis were established. To distinguish these 2 oyster groups, the VA C. ariakensis were placed in a mesh bag, while the NC C. ariakensis were free in the aquaria. As controls, 3 replicate aquaria each contained 50 free VA C. ariakensis and 50 bagged VA $C$. ariakensis. Aquaria were filled with $1 \mu \mathrm{m}$ filtered water of $\sim 20$ psu from the York River adjusted to $\sim 33$ to 35 psu by adding artificial sea salts (Crystal Sea, Marinemix) and maintained at $\sim 26$ to $28^{\circ} \mathrm{C}$ to mimic environmental conditions under which Bonamia exitiosa transmission to C. ariakensis occurs in the field (Carnegie et al. 2008). Oysters were fed a commercial algal paste (Shellfish Diet, Reed Mariculture) containing Isochrysis sp., Pavlova sp., Thalassiosira weissflogii and Tetraselmis sp. daily, and two-thirds of the water in each aquarium was changed 3 times a week. The water removed from the tanks was bleached and discarded as previously described (Audemard et al. 2008b). Mortality was checked daily, and dead animals were removed.

To assess the potential transmission of Bonamia exitiosa from infected (NC Crassostrea ariakensis) to uninfected C. ariakensis (i.e. the VA C. ariakensis), 10 and 20 VA $C$. ariakensis per treatment aquarium were sampled after 28 and 49 d of cohabitation, respectively. On the same dates, 23 August and 11 September 2007, an equal number of oysters was sampled from the VA $C$. ariakensis held in mesh bags in the 
control aquaria. The animals sampled were analyzed by PCR and histology to evaluate $B$. exitiosa infections (see 'B[.] exitiosa prevalence and ... intensity').

\section{Trial 2: Bonamia exitiosa incidence in Crassostrea ariakensis}

During this trial, the incidence of Bonamia exitiosa in Crassostrea ariakensis deployed in Bogue Sound euhaline waters in which $B$. exitiosa is enzootic was investigated. Incidence was defined as the percentage of oysters that became infected by this parasite during a specific time period. Since initial infections can be light and undetectable by histology and PCR, after uninfected animals were exposed to Bogue Sound waters for specific lengths of time, a subset of these animals was returned to VIMS and maintained under warm euhaline conditions in quarantine aquaria for several weeks, so infections acquired in Bogue Sound might develop to detectable levels.

On 2 August 2007, several hundred Crassostrea ariakensis produced at VIMS were deployed in upwellers located at the IMS and receiving Bogue Sound water as described above. These oysters were $18 \pm 2 \mathrm{~mm}$ (mean $\pm \mathrm{SD}$ ) in shell height. After $4 \mathrm{~d}$ and subsequently after 7, 14, 21 and $28 \mathrm{~d}$ of exposure to Bogue Sound waters, subsets of the deployed $C$. ariakensis (NC C. ariakensis) were shipped back to VIMS (Fig. 1). In order to assess the general water temperature trend during the exposure of $C$. ariakensis to Bogue Sound waters, water temperature data collected at hourly intervals at the NOAA monitoring station at Beaufort, North Carolina (Station I.D. 8656483), <5 $\mathrm{km}$ from the Bogue Sound upweller system in which all the oysters were held, were used.

For each of these exposure times, on the date of return of the NC Crassostrea ariakensis to VIMS, 3 treatment aquaria were established, each containing $50 \mathrm{NC} \mathrm{C}$. ariakensis and $50 \mathrm{VA}$ C. ariakensis from the same cohort, which had been maintained at the VIMS hatchery (Fig. 1). These VA $C$. ariakensis were placed in mesh bags to distinguish them from the oysters returning from Bogue Sound. By placing oysters returning from NC in cohabitation with unexposed and presumably healthy oysters, we intended to assess potential Bonamia exitiosa transmission under these laboratory conditions. Upon arrival in the laboratory, an additional $30 \mathrm{NC}$ C. ariakensis and 30 VA C. ariakensis were fixed for further PCR and histological analyses to determine whether $B$. exitiosa could be detected prior to initiation of laboratory exposure. As a control, 3 aquaria each containing 50 free VA $C$. ariakensis and 50 VA $C$. ariakensis held in a mesh bag were established on the date of the deployment of the oysters in Bogue Sound, i.e. on 2 August 2007.

All the oysters (treatment and control aquaria) were maintained at 33 to $35 \mathrm{psu}$ and $\sim 26$ to $28^{\circ} \mathrm{C}$. Mortality was checked daily, and any dead animals were removed. After the last aquaria (28 d exposure

\section{Bonamia exitiosa-enzootic area: \\ Bogue Sound, North Carolina $\left(28-30^{\circ} \mathrm{C}\right.$; $\left.>32 \mathrm{psu}\right)$}

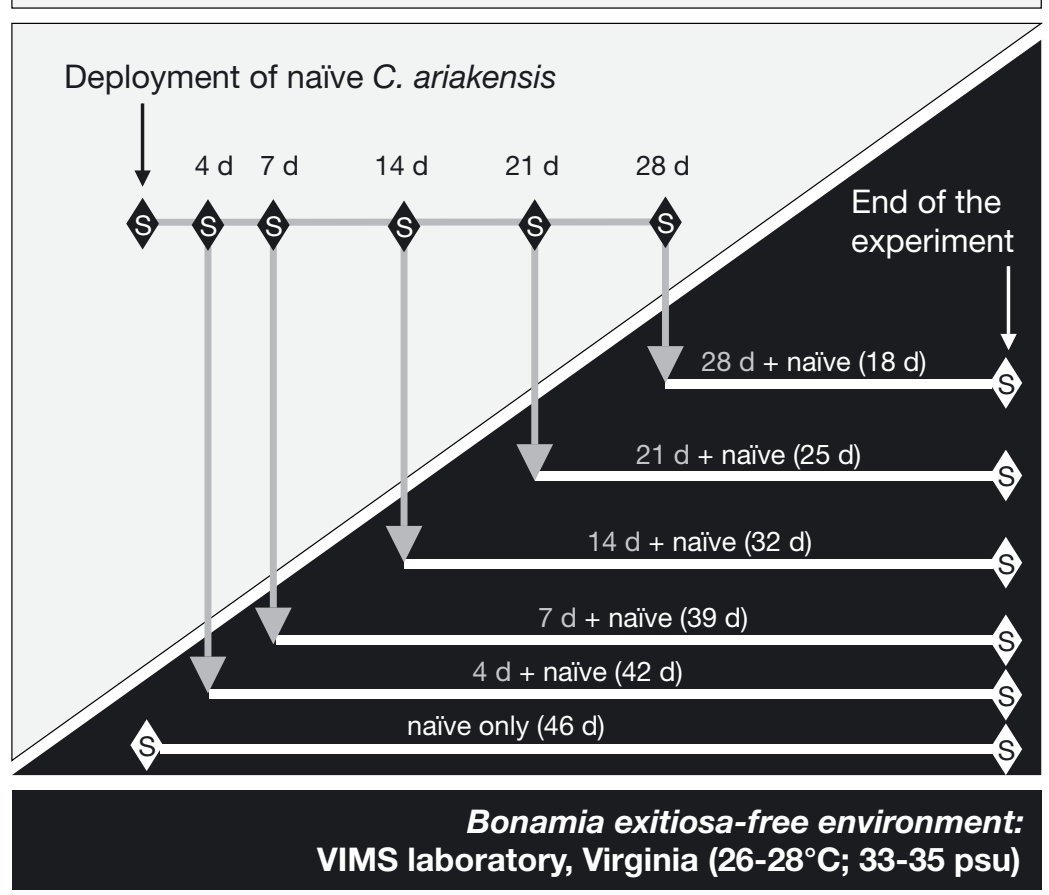

Fig. 1. Experimental design for investigation of Bonamia exitiosa incidence in Crassostrea ariakensis. Upper left corner with light grey background represents the enzootic area, Bogue Sound, NC; lower right with black background represents the Virginia Institute of Marine Science (VIMS) quarantine laboratory. After deployment of naïve C. ariakensis in Bogue Sound, samples were collected after 4, 7, 14, 21 and $28 \mathrm{~d}$ of exposure and returned to VIMS. Some of these sampled oysters were analyzed for $B$. exitiosa infections directly upon collection, while a subset was placed in aquaria in cohabitation with naïve $C$. ariakensis, free of $B$. exitiosa infections, for the number of days specified in parentheses. 'S' indicates when an oyster sample was collected for PCR and histology analyses 
treatment) were established, all the aquaria were maintained for an additional $18 \mathrm{~d}$ under laboratory conditions (Fig. 1). At the end of the experiment, 10 NC Crassostrea ariakensis and 10 VA C. ariakensis were sampled from each aquarium to assess the timing of Bonamia exitiosa infection acquisition in the field and potential transmission of the parasite under laboratory conditions. Ten free VA C. ariakensis and 10 bagged VA $C$. ariakensis were sampled from each control aquarium to confirm that these oysters had remained free of $B$. exitiosa. These animals were analyzed by PCR and histology as described below.

\section{Assessment of cumulative oyster mortality}

Cumulative mortality was calculated for each aquarium and at each sampling date $(28$ and $49 \mathrm{~d}$ exposure) for the transmission trial. For the incidence trial, cumulative mortalities within the aquaria were assessed at the 4 and $7 \mathrm{~d}$ time points of the experiment and subsequently on a weekly basis until the end of laboratory exposure. At each time point, average cumulative mortalities and standard errors were calculated as described by Audemard et al. (2008b).

\section{Bonamia exitiosa prevalence and average parasite intensity}

After each sampling, all the oysters collected were shucked, and a tissue sample of $\sim 3$ to $5 \mathrm{~mm}^{3}$ comprising some gill, mantle and visceral mass tissue was fixed in $95 \%$ ethanol for DNA extraction. A 5 mm thick standard section of each oyster (anterior to the adductor muscle, including digestive gland, stomach/intestine, gonad, mantle and gills) was fixed for $24 \mathrm{~h}$ in Davidson's fixative (Shaw \& Battle 1957) for subsequent paraffin histology performed using standard methods.

DNA was extracted from ethanol-preserved tissue using a DNeasy Tissue Kit (QIAGENTM) following the manufacturer's protocol. DNA was quantified with a GeneQuant pro spectrophotometer (Amersham Biosciences).

A PCR utilizing Bonamia genus small subunit rDNA-specific primers $C_{F}$ and $C_{R}$ was used to analyze all the oysters collected during the transmission and incidence trials (Carnegie et al. 2000). The only other Bonamia species present in North Carolina, $B$. perspora (Carnegie et al. 2006), has never been observed to infect Crassostrea ariakensis and has never been detected by PCR in association with this oyster. Thus, all C. ariakensis tested to be Bonamiapositive using this generic PCR assay were assumed to be infected with $B$. exitiosa. PCR-positive animals were analyzed by histology to confirm infection and to document its intensity. The initial screening by PCR saved time and the costs that would be associated with the histological analysis of all the samples. A $25 \mu \mathrm{l}$ total PCR reaction volume included $1 \times$ PCR buffer, $1.5 \mathrm{mM} \mathrm{MgCl}_{2}, 0.2 \mathrm{mM}$ dNTPs, bovine serum albumin (BSA) at $0.4 \mu \mathrm{g} \mathrm{ul}^{-1}, 0.25 \mu \mathrm{M}$ primers, Ampli-

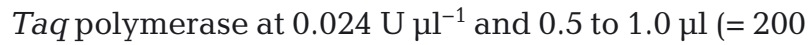
to $250 \mathrm{ng}$ ) template DNA. Each PCR experiment included a known $B$. exitiosa-positive sample as a positive control and a no-template sample (DNA replaced with water) as a negative control. Temperature cycling included a 4 min initial denaturation at $94^{\circ} \mathrm{C}$; followed by 35 cycles of denaturation at $94^{\circ} \mathrm{C}$, annealing at $59^{\circ} \mathrm{C}$, and extension at $72^{\circ} \mathrm{C}$ for $1 \mathrm{~min}$ each; and then a final extension at $72^{\circ} \mathrm{C}$ for $10 \mathrm{~min}$. Amplification products were electrophoresed in $2 \%$ agarose gels (in $1 \times \mathrm{TAE}$ ), stained with ethidium bromide and visualized under UV light. PCR prevalence was calculated as the percentage of oysters in which $B$. exitiosa DNA was amplified, and standard errors were calculated.

After fixation in Davidson's fixative, tissue from PCR-positive oysters was processed for standard paraffin histology. Slides were evaluated under oil immersion at 400 to $1000 \times$ magnification. Intensity of Bonamia exitiosa infection was rated at 0.5 (rare infection: 1 to $10 \mathrm{~B}$. exitiosa cells were observed in the entire section), 1 (light infection: 11 to $40 \mathrm{~B}$. exitiosa cells were observed), 3 (moderate infection: $>40$ cells were observed, but at densities of $<5$ cells in some fields), or 5 (heavy infection: $B$. exitiosa was present in all fields at densities of $\geq 5$ cells field $^{-1}$ ). Prevalence was calculated as the percentage of oysters with $B$. exitiosa infections, as confirmed by histology. Average $B$. exitiosa infection intensity was calculated as the sum of all infection intensity scores divided by the total number of infected animals. Standard errors were calculated for both prevalence and average parasite intensity.

\section{RESULTS}

\section{Trial 1: Bonamia exitiosa transmission}

After an exposure of $35 \mathrm{~d}$ to Bogue Sound waters, $96.5 \%$ of the NC Crassostrea ariakensis were found to be infected with generally light to moderate Bonamia exitiosa infections (average intensity score: 
2.3). These oysters were placed in cohabitation with initially uninfected VA $C$. ariakensis to assess potential transmission of the parasite. Cumulative mortality observed for the bagged and free VA $C$. ariakensis from the control aquaria, as well as for the VA $C$. ariakensis from the treatment aquaria, remained negligible $(<4 \%)$ during the duration of the experiment (Fig. 2A). NC C. ariakensis, on the contrary, showed cumulative mortality of $\geq 85 \%$ within $28 \mathrm{~d}$.

After 28 d of cohabitation, Bonamia exitiosa DNA was detected by PCR in an average of $13 \%$ of the initially uninfected VA Crassostrea ariakensis (Fig. 2B). Rare B. exitiosa infections (average score: 0.17) were confirmed by histology at this time point for an average histological prevalence of $3 \%$ (Fig. 2B). After $49 \mathrm{~d}$ of cohabitation, PCR and histological prevalence of $B$. exitiosa in the treatment VA $C$. ariakensis had
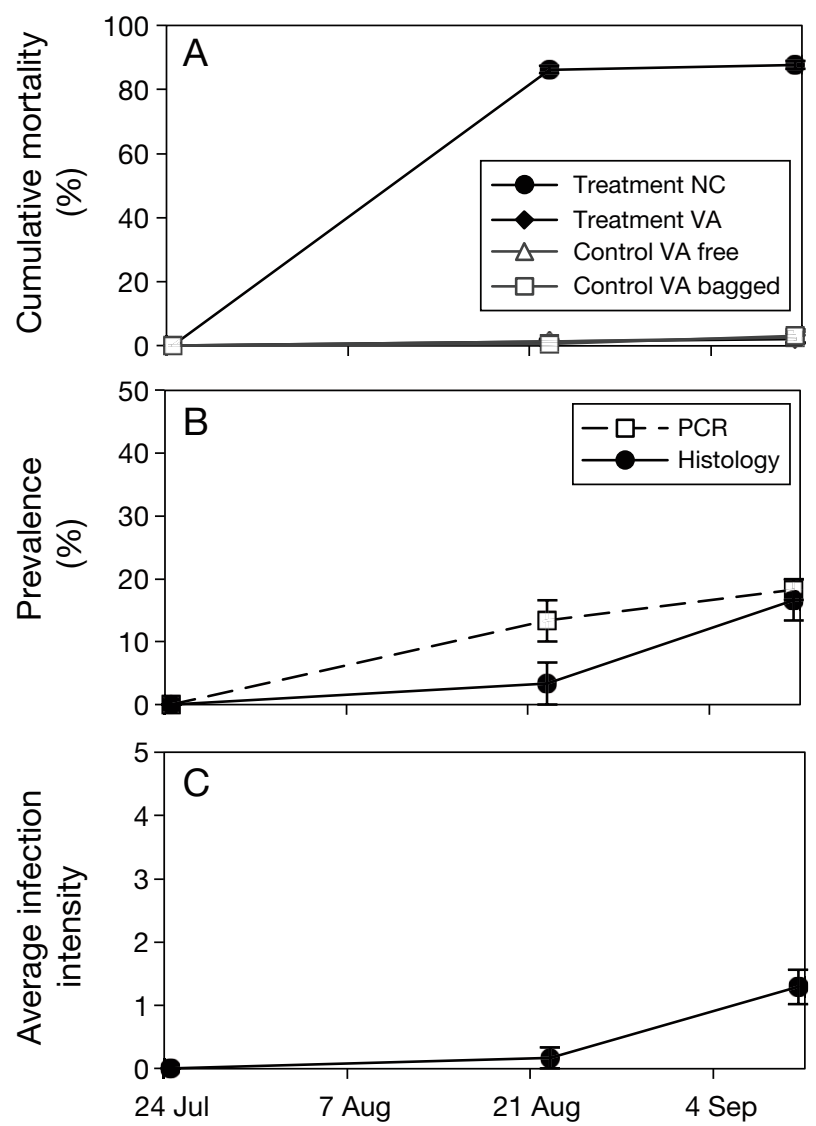

Fig. 2. Bonamia exitiosa infecting Crassostrea ariakensis. Results of the transmission trial. (A) Cumulative mortality measured in the oysters from the treatment and control aquaria after $28 \mathrm{~d}$ (23 August) and $49 \mathrm{~d}$ (11 September) of cohabitation. (B) B. exitiosa PCR and histology prevalence in the VA $C$. ariakensis placed in cohabitation with NC C. ariakensis. (C) Average parasite infection intensity in VA C. ariakensis determined by histology. Error bars $=1 \mathrm{SE}$ increased to an average of 18 and $16 \%$, respectively. Observed infection intensities (Fig. 2C) were higher than at the $28 \mathrm{~d}$ time point and ranged from rare to moderate (average score: 1.29). None of the VA $C$. ariakensis samples from the control aquaria were found to harbor $B$. exitiosa.

\section{Trial 2: Bonamia exitiosa incidence}

Samples collected directly after exposure to Bogue Sound waters

During the exposure to Bogue Sound waters from 2 to 30 August 2007, average daily temperatures measured at the nearby Beaufort NOAA station ranged from 28 to $30^{\circ} \mathrm{C}$ and salinities were $>32 \mathrm{psu}$.

Using PCR, Bonamia exitiosa DNA was first detected after $14 \mathrm{~d}$ exposure in $3.3 \%$ of the oysters collected (Fig. 3A). When analyzed by histology, all the oysters that were positive by PCR were confirmed to harbor $B$. exitiosa infections that were rare in intensity (Fig. 3B). After $21 \mathrm{~d}$ of exposure, 30\% of the oysters were positive using PCR, but infection by $B$. exitiosa was confirmed in only a minority of these oysters; histological prevalence remained as low as $3.3 \%$ and $B$. exitiosa infections were rare in intensity
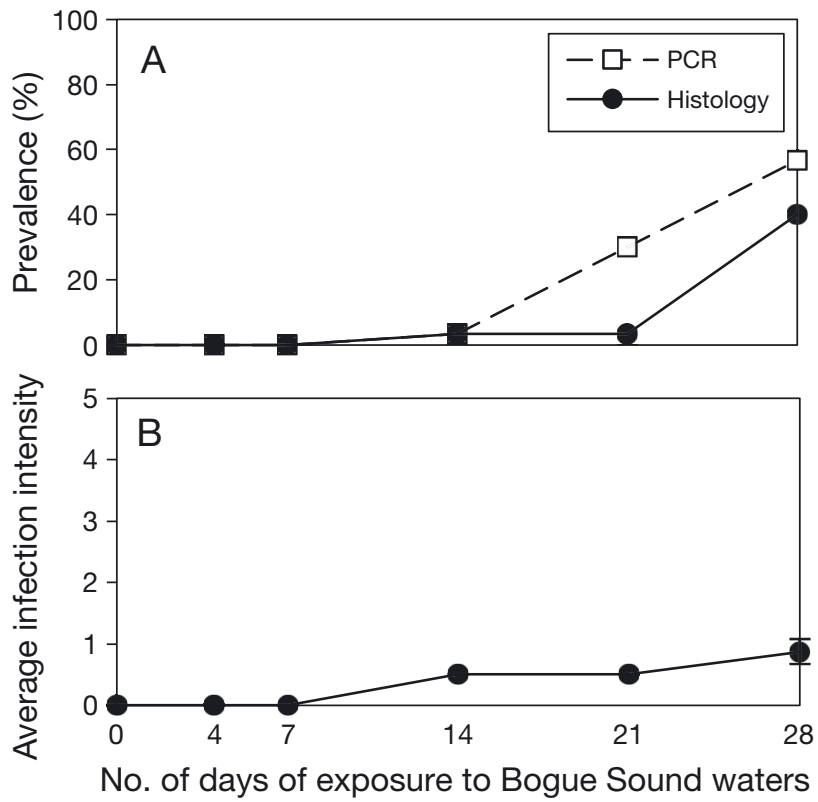

Fig. 3. Bonamia exitiosa infecting Crassostrea ariakensis. B. exitiosa in NC C. ariakensis from the incidence trial directly upon return from their exposure to Bogue Sound, NC, waters from 2 to 30 August. (A) PCR and histology prevalence and (B) average infection intensity determined by histology.

Error bars $=1 \mathrm{SE}$ 
(average score: 0.5). Finally, after $28 \mathrm{~d}$ of exposure, $56.7 \%$ of the oysters were positive by PCR and $40 \%$ were confirmed to harbor $B$. exitiosa infections ranging from rare to moderate in intensity (average score: 0.8$)$.

\section{Samples collected after additional laboratory exposure}

Independent of the treatment (control or treatment aquaria) and of oyster origin (VA or NC), average cumulative mortalities remained $<21 \%$ (Fig. 4) at the final sampling date (20 September 2007). By the end of the laboratory exposure, the highest cumulative mortality values were measured in NC Crassostrea ariakensis that had been exposed to Bogue Sound waters for 21 and $28 \mathrm{~d}$ (Fig. 4A). The bagged VA $C$. ariakensis exposed to the NC C. ariakensis 4 d treat-
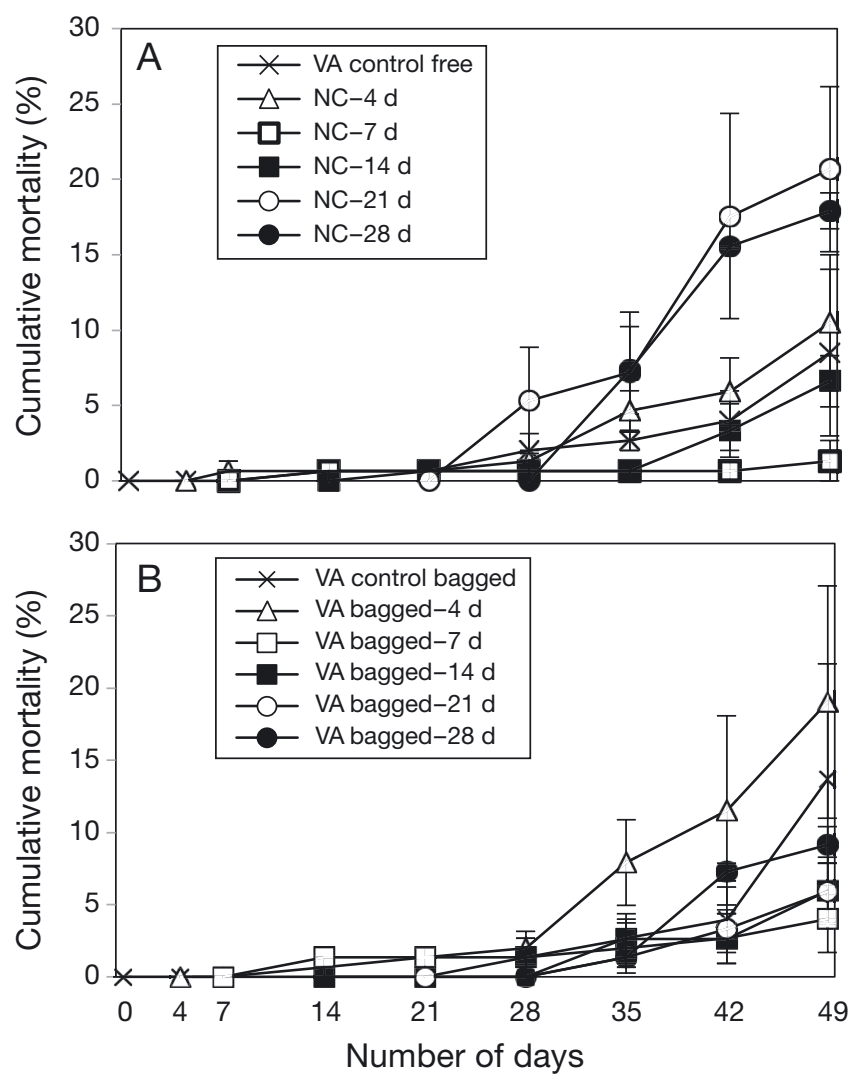

Fig. 4. Bonamia exitiosa infecting Crassostrea ariakensis. Cumulative mortality measured in oysters from the control and treatment aquaria from the incidence trial. (A) Cumulative mortality in the VA C. ariakensis-free control and in the NC C. ariakensis exposed to Bogue Sound waters for the specified length of time and (B) Cumulative mortality in the bagged VA $C$. ariakensis placed in cohabitation with NC $C$. ariakensis exposed for the specified length of time to Bogue Sound waters. Error bars $=1 \mathrm{SE}$ ment also showed some of the highest values recorded during this trial (Fig. 4B).

By the end of laboratory exposure (Fig. 5A), the PCR and histological analyses of the NC Crassostrea ariakensis from the different treatments showed higher prevalence of Bonamia exitiosa than was measured directly upon return of oysters from the field (Fig. 3A). B. exitiosa was not detected by PCR in any of the sampled VA C. ariakensis placed in cohabitation with these NC C. ariakensis. Average PCR prevalence in the NC C. ariakensis was 73 and $70 \%$ for 4 and $7 \mathrm{~d}$ treatments, respectively, and histological prevalence was $43.3 \%$ for both treatments. The $14 \mathrm{~d}$ treatment showed an increase in both PCR (90\%) and histological prevalence (77\%) compared to the 4 and $7 \mathrm{~d}$ treatments. The $21 \mathrm{~d}$ treatment was characterized by $100 \%$ B. exitiosa prevalence as measured by both PCR and histology. Finally, the 28 d treatment showed a decrease in both PCR (90\%) and histological (77\%) prevalence. For all these different treatments average parasite infection intensities were light to moderate (Fig. 5B).

\section{DISCUSSION}

In the present study, transmission of Bonamia exitiosa from infected Crassostrea ariakensis to uninfected $C$. ariakensis held together under warm euha-
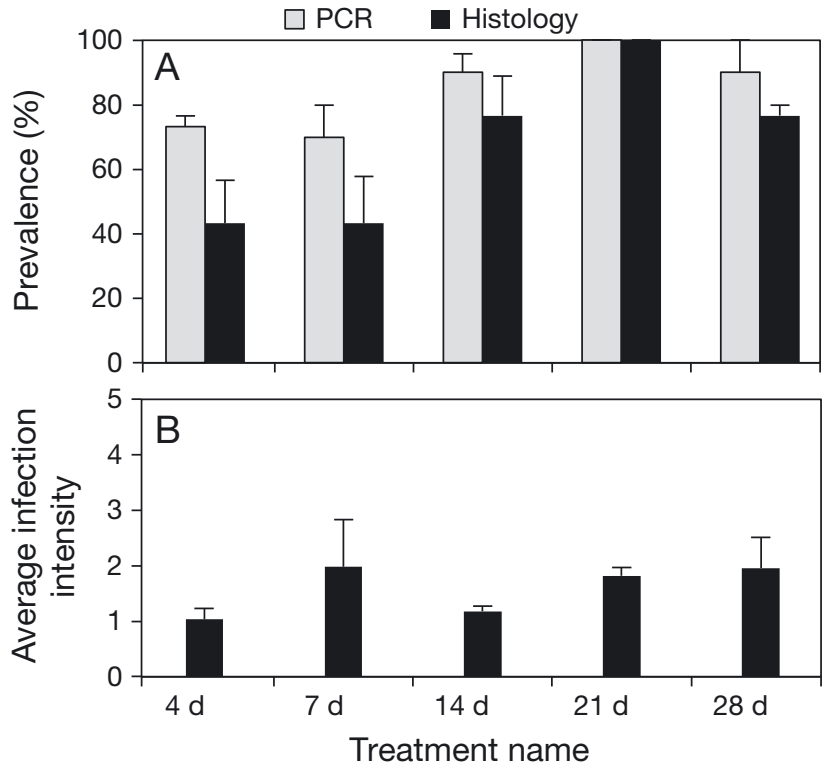

Fig. 5. Bonamia exitiosa infecting Crassostrea ariakensis. B. exitiosa in NC C. ariakensis from the incidence trial after additional laboratory exposure. (A) PCR and histology prevalence and (B) average infection intensity determined by histology. Error bars = $1 \mathrm{SE}$ 
line laboratory conditions was observed after only $28 \mathrm{~d}$ of cohabitation. The experimental transmission of Bonamia spp. parasites during cohabitation of infected and non-infected hosts has previously been documented for $B$. ostreae in the flat oyster Ostrea edulis (Bachère et al. 1986, Elston et al. 1986, 1987, Culloty et al. 1999, Lallias et al. 2008). Results from a previous experiment also suggested that $B$. exitiosa may be directly transmitted among $O$. chilensis (Hine 1996). Similarly, the results of the present experiment suggest that $B$. exitiosa may be directly transmitted among $C$. ariakensis. It may be pointed out, however, that in spite of the filtration $(1 \mu \mathrm{m})$ of the water used during this experiment, the presence of small invertebrates such as harpacticoid copepods and annelids was noted in the experimental tanks by the end of the experiment. It remains possible that these invertebrates may have been involved in $B$. exitiosa transmission; however, these were not screened for $B$. exitiosa in this study, leaving their potential involvement in the $B$. exitiosa life-cycle unresolved. This trial, nevertheless, demonstrated that $B$. exitiosa does not require the native oyster $O$. stentina besides C. ariakensis to complete its life cycle.

The second trial demonstrated the high incidence of Bonamia exitiosa in Crassostrea ariakensis in natural waters under warm euhaline conditions. The absence of detectable $B$. exitiosa in cohabitating VA $C$. ariakensis during the incidence study suggested that the increased prevalence observed in NC $C$. ariakensis during their laboratory exposure was not a consequence of parasite transmission in aquaria. Rather, the prevalence increase represented increased detection of $B$. exitiosa infections as they became patent in the laboratory. The exposure of the NC $C$. ariakensis to favorable warm euhaline conditions in the laboratory for several weeks allowed the parasites acquired in Bogue Sound to proliferate within their hosts so that detectable levels of infection could be reached. As a consequence, the prevalence levels observed at the end of the laboratory exposure period reflected more accurately the incidence of $B$. exitiosa than the prevalence observed directly after the animals were sampled from the field. Although $B$. exitiosa was not detected by PCR or histology directly upon return from the field after a $4 \mathrm{~d}$ exposure, likely reflecting very small numbers of parasite cells focally distributed within host tissues and either missed during sampling or below amplifiable levels, the additional laboratory exposure revealed that $>40 \%$ of these oysters were infected by $B$. exitiosa, as determined by histology. The PCR prevalence was $73 \%$ for the
4 d exposure treatment. PCR only indicates the detection of DNA, which may not always be associated with the presence of viable parasite cells responsible for an infection (Burreson 2008). In this study, however, the fact that the $B$. exitiosa DNA was not detected in the cohabiting VA $C$. ariakensis suggests that PCR detection in the NC C. ariakensis may actually be indicative of parasite infections. It has been documented in other studies that PCR is generally more sensitive than histology (Balseiro et al. 2006), which would support the lower prevalence obtained by histology compared to PCR.

Transmission was not observed in the present incidence trial during which NC Crassostrea ariakensis exposed to Bogue Sound waters for various lengths of time were placed in aquaria with VA C. ariakensis. In this experiment, however, the NC C. ariakensis from the incidence trial were only lightly infected at the onset of their cohabitation with non-infected $C$. ariakensis. The combination of potentially very light Bonamia exitiosa infections and the dilution of waterborne infective stages of $B$. exitiosa through water changes may explain the absence of transmission in this trial. In contrast, at the onset of the transmission trial, B. exitiosa prevalence in the NC C. ariakensis was $96.5 \%$, with infection intensities ranging from light to moderate, which was likely associated with the release of sufficient $B$. exitiosa infective cells over time in the aquaria to infect the cohabitating noninfected oysters in spite of the water changes. As a final comment on transmission, we note again that transmission also failed in an earlier study (Audemard et al. 2008a). We must conclude that our small research aquaria are not conducive to the full $B$. exitiosa activity that would be displayed in natural waters. Whether this relates to biological factors or to physical factors such as water chemistry is not known.

In summary, this study emphasized 2 factors central to the rapid development of Bonamia exitiosa epizootics in experimental Crassostrea ariakensis populations in Bogue Sound under warm euhaline conditions: a high incidence of infection and, however imperfectly captured in our experimental systems, the high likelihood of direct transmissibility. Although Asian $C$. ariakensis were not introduced to open waters of the eastern USA as had been proposed, the threat of $B$. exitiosa will remain for hatcheries located in $B$. exitiosa-enzootic areas that produce $C$. ariakensis for aquaculture elsewhere (Grabowski et al. 2007). The high susceptibility of $C$. ariakensis to $B$. exitiosa should also not escape the notice of shellfish health managers in Asia. 
Acknowledgements. This research was funded by the National Oceanographic and Atmospheric Administration's Chesapeake Bay Office (Grant Number NA04NMF457 0422). We thank S. Denny for processing the histology samples, R. Crockett for evaluating the slides, and the VIMS Aquaculture Genetics and Breeding Technology Center for providing the triploid C. ariakensis. We also thank M. Wong, J. Beasley and D. Schmitt from the University of North Carolina Institute of Marine Sciences for maintaining animals for use in these experiments. This paper is Contribution No. 3353 of the Virginia Institute of Marine Science, College of William \& Mary.

\section{LITERATURE CITED}

Abollo E, Ramilo A, Casas SM, Comesaña P, Cao A, Carballal MJ, Villalba A (2008) First detection of the protozoan parasite Bonamia exitiosa (Haplosporidia) infecting flat oyster Ostrea edulis grown in European waters. Aquaculture 274:201-207

Audemard C, Carnegie RB, Stokes NA, Bishop MJ, Peterson $\mathrm{CH}$, Burreson EM (2008a) Effects of salinity on Bonamia sp. survival in the Asian oyster Crassostrea ariakensis. J Shellfish Res 27:535-540

Audemard C, Carnegie RB, Bishop MJ, Peterson CH, Burreson EM (2008b) Interacting effects of temperature and salinity on Bonamia sp. parasitism in the Asian oyster Crassostrea ariakensis. J Invertebr Pathol 98: 344-350

Bachère $\mathrm{E}$, Comps M, Grizel H (1986) Infections expérimentales de l'huitre plate Ostrea edulis L. par le protozoaire Bonamia ostreae. In: Vivares CP, Bonami JR, Jaspers E (eds) Pathology in marine aquaculture. Special Publication No. 9, European Aquaculture Society, Bredene, p 127-132

Balseiro P, Fernandez Conchas R, Montes J, Gómez-León J, Novoa B, Figueras A (2006) Comparison of diagnosis techniques for the protozoan parasite Bonamia ostreae in flat oyster Ostrea edulis. Aquaculture 261:1135-1143

Berthe F, Hine P (2003) Bonamia exitiosa Hine et al., 2001 is proposed instead of $B$. exitiosus as the valid name of Bonamia sp. infecting flat oysters Ostrea chilensis in New Zealand. Dis Aquatic Org 57:181

Bishop MJ, Carnegie RB, Stokes NA, Peterson CH, Burreson EM (2006) Complications of a non-native oyster introduction: facilitation of a local parasite. Mar Ecol Prog Ser 325:145-152

Burreson EM (2008) Misuse of PCR assay for diagnosis of mollusc protistan infections. Dis Aquat Org 80:81-83

Burreson EM, Stokes NA, Carnegie RB, Bishop MJ (2004) Bonamia sp. (Haplosporidia) found in non-native oysters Crassostrea ariakensis in Bogue Sound, North Carolina. J Aquat Anim Health 16:1-9

Editorial responsibility: Marc Engelsma, Lelystad, The Netherlands
Carnegie RB, Barber BJ, Culloty SC, Figueras AJ, Distel DL (2000) Development of a PCR assay for detection of the oyster pathogen Bonamia ostreae and support for its inclusion in the Haplosporidia. Dis Aquat Org 42:199-206

> Carnegie RB, Burreson EM, Hine PM, Stokes NA, Audemard C, Bishop MJ, Peterson CH (2006) Bonamia perspora n. sp. (Haplosporidia), a parasite of the oyster Ostreola equestris, is the first Bonamia species known to produce spores. J Eukaryot Microbiol 53:232-245

> Carnegie RB, Stokes NA, Audemard C, Bishop MJ and others (2008) Strong seasonality of Bonamia sp. infection and induced Crassostrea ariakensis mortality in Bogue and Masonboro Sounds, North Carolina, USA. J Invertebr Pathol 98:335-343

> Corbeil S, Arzul I, Robert M, Berthe F, Besnard-Cochennec N, Crane M (2006) Molecular characterisation of an Australian isolate of Bonamia exitiosa. Dis Aquat Org 71: 81-85

Culloty SC, Novoa B, Pernas M, Longshaw M, Mulcahy MF, Feist SW, Figueras A (1999) Susceptibility of a number of bivalve species to the protozoan parasite Bonamia ostreae and their ability to act as vectors for this parasite. Dis Aquat Org 37:73-80

Elston RA, Farley CA, Kent ML (1986) Occurrence and significance of bonamiasis in European flat oysters Ostrea edulis in North America. Dis Aquat Org 2:49-54

Elston RA, Kent ML, Wilkinson MT (1987) Resistance of Ostrea edulis to Bonamia ostreae infection. Aquaculture 64:237-242

> Grabowski JH, Peterson CH, Bishop MJ, Conrad R (2007) The bioeconomic feasibility of culturing triploid Crassostrea ariakensis in North Carolina. J Shellfish Res 26: 529-542

Hill KM, Carnegie RB, Aloui-Bejaoui N, El Gharsalli R, White DM, Stokes NA, Burreson EM (2010) Observation of a Bonamia sp. infecting the oyster Ostrea stentina in Tunisia, and a consideration of its phylogenetic affinities. J Invertebr Pathol 103:179-185

Hine PM (1996) The ecology of Bonamia and decline of bivalve molluscs. NZ J Ecol 20:109-116

Hine PM, Cochennec-Laureau N, Berthe F (2001) Bonamia exitiosus n. sp (Haplosporidia) infecting flat oysters Ostrea chilensis in New Zealand. Dis Aquat Org 47:63-72

Lallias D, Arzul I, Heurtebise S, Ferrand S and others (2008) Bonamia ostreae-induced mortalities in one-year old European flat oysters Ostrea edulis: experimental infection by cohabitation challenge. Aquat Living Resour 21: 423-439

Shaw BL, Battle HI (1957) The gross and microscopic anatomy of the digestive tract of the oyster Crassostrea virginica (Gmelin). Can J Zool 35:325-346

Shilts MH, Pascual MS, Ó Foighil D (2007) Systematic, taxonomic and biogeographic relationships of Argentine flat oysters. Mol Phylogen Evol 44:467-473

Submitted: April 4, 2013; Accepted: July 8, 2013 Proofs received from author(s): February 17, 2014 